\title{
From the Manipulation of Literary Translation to the Manipulation of Literary Creation: A Case Study*
}

\author{
KE Yi-man, ZHU Xiang-jun \\ College of Foreign Studies, Jinan University, Guangzhou, China
}

\begin{abstract}
Manipulation always means a kind of extraordinary alteration for some purposes. All translation implies a degree of manipulation of the source text for a certain purpose. Liang Shih-chiu's literary translation serves for his literary creation which aims to promote colloquialism and to construct New Literature in the May Fourth Movement. Literary translation is the foundation of literary creation, or rather, its important strategy. The paper, from the perspective of Manipulation Theory, analyzes the purpose and strategy of Liang Shih-chiu's literary translation and explores the influence of his literary translation upon his literary creation in terms of ideology, poetics and patronage.
\end{abstract}

Keywords: manipulation, literary translation, literary creation, Liang Shih-chiu

\section{Introduction}

Liang Shih-chiu (1903-1987), one of the greatest essayists and translators in China, has written thirty-one collections of essays including four-volume Yasha Xiaopin (From a Cottager's Sketchbook). He single-handedly translated William Shakespeare: Complete Works, which includes thirty-seven plays and three collections of poems, for nearly forty years. He spent seven years in writing a comprehensive history of English literature in Chinese, which consists of a three-volume history and a companion set of Selected Readings in English Literature in Chinese translation, also in three volumes. Besides, he compiled Far East English-Chinese Dictionary. Liang is an expert in both Chinese and Western knowledge. His writing, combined with features of English literature and Chinese literature, has unique artistic characteristics. His translation follows the principle of being faithful to the original rather than being elegant. Liang believed that "faithfulness to the original is the base for translation, upon which translators can pursue fluency” (Liang, 1967, pp. 75-76). Liang owes his literary creation to his literary translation, which is not only the basis of his literary creation but also an important method for his literary reform and vernacular Chinese ${ }^{1}$ creation. The paper, from the perspective of Manipulation Theory,

\footnotetext{
* Acknowledgements: This research is sponsored by Philosophy and Social Science Program of Guangdong, Project Number: GD15CWW09.

KE Yi-man, Postgraduate of Translation at College of Foreign Studies, Jinan University.

ZHU Xiang-jun, Ph.D., Associate Professor, majoring in English teaching, translation practice and research.

${ }^{1}$ Vernacular Chinese (simplified Chinese) refers to forms of written Chinese based on the varieties of Chinese spoken throughout China, in contrast to Classical Chinese, the written standard used during imperial China up to the early twentieth century. Since the early 1920s, this modern vernacular form has been the standard style of writing for speakers of all varieties of Chinese throughout mainland China, Taiwan, Malaysia and Singapore as the written form of Modern Standard Chinese.
} 
analyzes the purposes and strategies of Liang Shih-chiu's literary translation and explores the influence of his literary translation upon his literary creation in terms of patronage, ideology and poetics.

\section{Manipulation of Literary Translation}

Manipulation theory of literary translation was produced in Europe in the late 1960s while the concept of manipulation was officially confirmed in the late twentieth century. In The Manipulation of Literature: Studies in Literary Translation, Hermans wrote: "All translation implies a degree of manipulation of the source text for a certain purpose” (1985, p. 11). Translational actions, according to the manipulation theory, are not only simple transferring between languages, but also literary embodiments closely related with social system, political consciousness, public psychology and so on. Translators promote literature development and literary communication by incorporating individual understanding of the source texts and using new expressions and different literary genres. Andre Lefevere developed the manipulation theory in his Translation, Rewriting and the Manipulation of Literary Fame, arguing that "translation is, of course, a rewriting of an original text ... rewriting is manipulation" (2004b, p. vii). He believed that "translation needs to be studied in connection with power and patronage, ideology and poetics, with emphasis on the various attempts to shore up or undermine an existing ideology or an existing poetics” (Lefevere, 2004b, p. 10).

\section{Patronage}

Lefevere thought that "patronage will be understood to mean something like the powers (persons, institutions) that can further or hinder the reading, writing, and rewriting of literature” (2004b, p. 15). Patrons provide economic support, social status and ideological suggestion for the translators or writers.

After Liang Shih-chiu returned from America, he got acquainted with Hu Shih ${ }^{2}$ in Crescent Moon Monthly and accepted his ideas about new literature clearly stated out in his essays The Attempting Discussion of Literary Reform and The Construction of Literary Revolution. Hu originally organized five scholars to translate William Shakespeare: Complete Works (but only Liang remained) and he attempted literary reform and required using literal translation in vernacular Chinese to translate Western English classics (HU, 1993, pp. 19, 47, 53). In a letter to Liang in 1931, he proposed that,

... (ii) The Complete Works is supposed be finished in five years. (Approximately, for half of a year one can translate a play and its revise needs almost the same period of time... (v) As for the translation style, it is not appropriate to stipulate but better to translate into prose with rhythm. Don't paraphrase. One can add detailed notes when hard to translate. ... (vii) The expenditure of each play is RMB XX yuan including the remuneration and some other fees. (HU, 1996, p. 540)

These requirements are illustrated in Liang's translation.

Adding an annotation. For readers to better understand puns, literary quotations and some other cultural words in the source text, Liang added annotations in all his translations.

[Example 1] [ST] HELENA ... Yet Hermia still loves you: then be content.

[TT] 海......荷米亚爱的是你, 你该满足。 (Liang, 2001a, pp. 74-75)

\footnotetext{
${ }^{2}$ Hu Shih (1891-1962) is a Chinese philosopher and essayist who is widely recognized today as a key contributor to Chinese liberalism. He is one of the leading and most influential intellectuals during the May Fourth Movement and later the New Culture Movement.
} 
[Annotation] 注释: 原文content有二义, 海伦娜谓“镇定”之义, 莎式英语常有此种用法, 地美特利阿斯误为“满 足”之义。此双关语, 译文未能表达。

Change of literary forms. Liang translated original poetic style into prose style.

[Example 2] [ST] ROMEO But, soft! What light through yonder window breaks? / It is the east, and Juliet is the sun! / Arise, fair sun, and kill the envious moon. / ... / Two of the fairest stars in all the heaven, / Having some business, do entreat her eyes / To twinkle in their spheres till they return.

[TT] 罗: 小声些! 窗口那边透出的是什么光亮? 那是东方, 朱丽叶就是太阳! 升起来吧, 美丽的太阳, 杀掉 那嫲妒的月亮……上两颗最灿烂的星, 因公外出, 在归位之前央求她的眼睛代替他们在星座中闪烁。(Liang, 2001c, pp. 74-77)

Liang literally translated words and phrases in prose style. He kept original meanings of "kill”, "having some business" and "till they return" in translation. But he also added some Chinese cultural information in his translation, like “归位” (guiwei, movements of stars).

\section{Ideology}

Ideology is a set of cultural beliefs, values, and attitudes of a social, religious, political, or corporate entity. It includes politics, law, thought, morality, literature art, religion, philosophy and other social sciences. Lefevere wrote in Translation, Rewriting and the Manipulation of Literary Fame (2004b): "Ideology would seem to be that grillwork of form, convention, and belief which orders our actions” (p. 16). "All rewritings, whatever their intention, reflect a certain ideology and a poetics and as such manipulate literature to function in a given society in a given way" (Lefevere, 2004b, p. vii).

The dominant ideology of the New Culture Movement ${ }^{3}$ is to use vernacular Chinese to translate Western classics literally so as to enrich Chinese by absorbing foreign expressions and to replace the classical litterateur with the vernacular literature in the end. When he pursued his graduate studies at Harvard, Liang Shih-chiu studied literary criticism under Irving Babbitt, whose New Humanism helped shape his conservative literary tenets. Liang believed "literature begins with humanity, bases on humanity, and also ends with humanity" (Liang, 1988, p. 122). William Shakespeare: Complete Works, a classical work that praises human nature, is certainly the first choice for his translation. Liang suggested that,

...translators should translate literary masterpieces rather than second-class literatures; they should translate original works rather than indirect works; they should use literal translation on the basis of sentence unit rather than paraphrase; and they should select works with academic or educational values rather than the works catering to readers alone. (2004, pp. 121, 124-125)

Let's look at some examples.

[Example 3] [ST] ANTONIO One, sir, that for his love dares yet do more / Than you have heard him brag to you he will.

[TT] 安图 先生, 我是为了对他的友爱而敢做比她对你夸口说敢做更多的事的一个人。(Liang, 2001b, pp. 140-141)

\footnotetext{
3 The New Culture Movement of the mid 1910s and 1920s sprang from the disillusionment with traditional Chinese culture following the failure of the Chinese Republic, founded in 1912 to address China's problems. Scholars like Chen Duxiu, Cai Yuanpei, Li Dazhao, Lu Xun, Zhou Zuoren, and Hu Shih, had classical educations but began to lead a revolt against Confucianism. They called for the creation of a new Chinese culture based on global and western standards, especially democracy and science.
} 
[Example 4] [ST] CLOWN I would be sorry, sir, but the food should be as oft with your master as with my mistress. I think I saw your wisdom there.

$[\mathrm{TT}]$ 丑 我很抱兼, 先生, 假如俊子不是常常在你的主人家像在我的主人家一样。我记得在那里我是见过您 这个聪明人。(Liang, 2001b, pp. 100-101)

In order to learn from the expressions of Western literature, Liang used literal translation on the basis of sentence unit to retain the textual features of the source text. His translation, although awkward in reading, is in line with the ideology of the time: to create a vernacular literature by absorbing Western literary characteristics.

\section{Poetics}

A poetics can be said to consist of two components: one is an inventory of literary devices, genres, motifs, prototypical characters and situations, and symbols; the other a concept of what the role of literature is, or should be, in the social system as a whole. (Lefevere, 2004b, p. 26)

It is a combination of literature and society. Literature is a mirror of society in mind, and translation is a mirror of literature in different language. Literary translation goes beyond the transfer of linguistic information and it emphasizes that imaginative originality resides as much in the translation as in the source text. To remain literary information of source texts well in target texts, translators have to pay attention to the characteristics of poetics which play a supporting role in construction of social and cultural context.

In New Culture Movement, the main literary genres are vernacular prose, play, poetry and novel. Scholars attempted to resort to the Europeanization of Chinese in literary translation to replace classical literature with vernacular literature. In 1922, Hu Shih concluded the achievements in the five-year development of vernacular literature by saying "the vernacular poem had been somewhat successful, the short story had started using vernacular Chinese, the vernacular prose had made great progress; however, the play and the novel had a long way to go" (HU, 2004, p. 193). For this reason, Hu sponsored Liang to translate William Shakespeare's plays. To make up for the deficiency in vernacular play, Liang changed the language forms and literary genres of the source text by using prose not verse, literal translation not paraphrase, full translation not selective translation.

[Example 5] [ST] ... Then the conceit of this inconstant stay / Sets you most rich in youth before my sight, / Where wasteful Time debateth with Decay, / To change your day of youth to sullied night; / And, all in war with Time for love of you, / As he takes from you, I engraft you new.

[TT ] ... 所以, 想到了人生无常, / 我愈发觉得你年少翩翩; / 这时节光阴正在和毁灭商量, / 要把你的 灿烂青春变为黑暗的夜晚; / 我为了爱你而与光阴奋斗, / 我要为你移殖新枝, 他要把你的生命夺走。(Liang, 2001d, pp. 38-39)

[Annotation] 注释：指诗人所做之诗篇。

Liang translated Shakespeare's sonnets by using vernacular free verse which later became one of the most important forms of Chinese poetry.

[Example 6] [ST] PYRAMUS ... For, by thy gracious, golden, glittering streams, / I trust to taste of truest Thisby’s sight...

[TT] 皮……靠了你的温柔的黄金的闪耀的光芒， / 可以看见我的最忠的提斯璧的模样 $\cdots . . .$. (Liang, 2001a, pp. 168-169) 
Liang kept the location of adjectives in the source text and placed them before the modified, which rarely occurs in classical Chinese.

[Example 7] [ST] MERCUTIO ... O Romeo, that she were, O that she were/ An open-arse, or thou apopp'rin' pear.

[TT] 墨 ……啊罗密欧! 真愿她是啊！真愿她是烂熟的裂开的“那活儿”, 你是一只生硬的大青梨…… (Liang, 2001a, pp. 74-75)

Liang attempted to translate the full of the source text, not omitting any words even with indecent ones.

\section{Manipulation of Literary Creation}

Manipulation of literary creation means intentional alteration of given literary norms or conventions, such as literary languages, literary forms, and literary methods and so on. In the New Culture Movement, the development of the vernacular in China has just begun. It was urgent to create some new expressions to enrich vernacular Chinese and the best way to do this is to absorb new expressions directly from foreign languages by translation. That is the reason why Liang Shih-chiu chose the literal translation for most cases, with little change of the source sentence structures. In his vernacular literary creation, the most typical expressions that Liang borrowed from English language are:

\section{Predicative Sentence With Link Verb “Be” ( “是.......” )}

Verb of being pattern is one of the most common sentences in English, but it rarely occurs in Classical Chinese. After some years of literal translation, Liang directly absorbed the expression ( “是......” ) and used it in his vernacular writing.

\section{[Example 8] 音乐这样东西, 在所有的艺术里, 是最富于侵略性的。(Liang, 2012a, p. 13) \\ [Example 9] 有些人家是很讲究禁忌的。(Liang, 2012b, p. 11)}

According to the publication time, four-volume Sketches of a Cottager, are divided into three periods (early period of 1949-1973, middle period of 1973-1982 and later period of 1982-1986). The right column is the number of predicative sentences that is counted from the first thousand words of the randomly-chosen proses in Liang's Sketches of a Cottager (see Table 1).

Table 1

Statistic of Predicative Sentence With Link Verb "Be" in Sketches of a Cottager

\begin{tabular}{lll}
\hline Publication time & Titles of works & Number of predicative sentences \\
\hline 1949 & 《音乐》Music & 19 \\
1949 & 《医生》Doctors & 16 \\
1973 & 《牙签》Toothpick & 20 \\
1973 & 《老年》Agedness & 18 \\
1982 & 《排队》Queuing Up & 19 \\
1982 & 《懒》Laziness & 15 \\
1986 & 《守时》Punctuality & 16 \\
1986 & 《奖券》Lottery & 17 \\
\hline
\end{tabular}

The data indicate that verb of being pattern is used more frequently in his early and middle writing periods than in his later period, which shows Liang preferred the Europeanization of Chinese at first but gradually turned to the conventional usage of Chinese to form his own writing style. 


\section{Premodification (“.......的”)}

In English language, two or more attributive adjectives are often placed before the head; however, in classical Chinese, the premodification ( $\cdots \cdots \cdots$ 的) like this is rarely used. Liang, through literal translation, came to accept the expression from English and gradually used it in his vernacular Chinese writing.

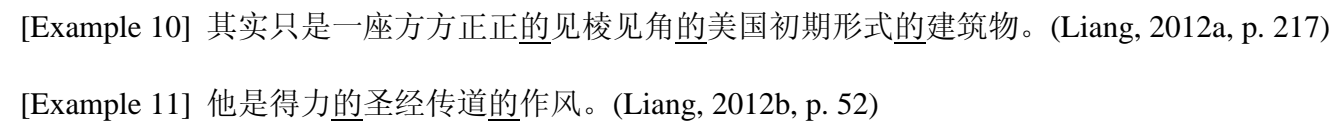

The right column is the number of premodification that is counted from the first thousand words of the randomly-chosen proses in Liang's Sketches of a Cottager (see Table 2).

Table 2

Statistic of Premodification in Sketches of a Cottager

\begin{tabular}{lll}
\hline Publication time & Titles of works & Number of premodifications \\
\hline 1949 & 《匿名信》Anonymous Letter & 36 \\
1949 & 《狗》Dogs & 38 \\
1973 & 《退休》Retirement & 32 \\
1973 & 《窗外》Out of the Window & 36 \\
1982 & 《年龄》Age & 34 \\
1982 & 《梦》Dream & 39 \\
1986 & 《职业》Job & 30 \\
1986 & 《高尔夫》Golf & 35 \\
\hline
\end{tabular}

The data indicate that a large number of premodifications are used in Liang's vernacular Chinese writing. It is because of the translators like Liang that the expression of premodification has become popular in modern Chinese.

\section{Subordinate Conjunctions}

Classical Chinese makes heavy use of parataxis where English would use a dependent clause. Sentences are often placed coordinately, with few conjunctions to link them. One of the biggest differences between classical Chinese and vernacular Chinese, which translation brought in, is the more use of subordinate conjunctions, which can be easily seen from Liang's vernacular Chinese writing below.

$$
\begin{aligned}
& \text { [Example 12] 在风飒飒雨霏霏的时候, 心情枯寂百无聊赖。(Liang, 2012a, p. 61) } \\
& \text { [Example 13] 尽管我们的计程车不满人意, 但不要忘记计程车的前一代的三轮车…… (Liang, 2012b, p. 262) }
\end{aligned}
$$

The right column is the number of subordinate conjunctions that is counted from the first thousand words of the randomly-chosen proses in Liang's Sketches of a Cottager (see Table 3).

Table 3

Statistic of Subordinate Conjunctions in Sketches of a Cottager

\begin{tabular}{lll}
\hline Publication time & Titles of works & Number of subordinate conjunctions \\
\hline 1949 & 《雅舍》The Cottager & 19 \\
1949 & 《客》Guests & 18 \\
1973 & 《I日》Reminiscence & 15 \\
1973 & 《睡》Sleep & 14 \\
1982 & 《双城记》Tales of Taipei and Seattle & 21 \\
\hline
\end{tabular}


(Table 3 continued)

\begin{tabular}{lll}
\hline Publication time & Titles of works & Number of subordinate conjunctions \\
\hline 1982 & 《书房》Study & 16 \\
1986 & 《废话》Nonsense & 18 \\
1986 & 《窝头》Steamed Bread of Corn & 14 \\
\hline
\end{tabular}

The data indicate that Liang Shih-chiu used quite a few subordinate conjunctions in his Chinese literary writing. He learns from literary translations directly and uses these English expressions in his vernacular Chinese writing. It is because of language borrowing like this that modern Chinese can express much more complicatedly than ever before.

Indefinite Articles (“-......”)

The rules of English grammar require that in most cases a noun, or more generally a noun phrase, must be "completed" with a determiner to clarify what the referent of the noun phrase is. The most common determiners are the articles the and $a(n)$, which specify the presence or absence of definiteness of the noun. But in Chinese, articles, particularly indefinite articles, are rarely used. For instance, “我是老师 (I am teacher)” is more preferable to “我是一位老师 (I am a teacher)”. Liang Shih-chiu began to use indefinite articles in his translation and retained the expression in his Chinese literary writing.

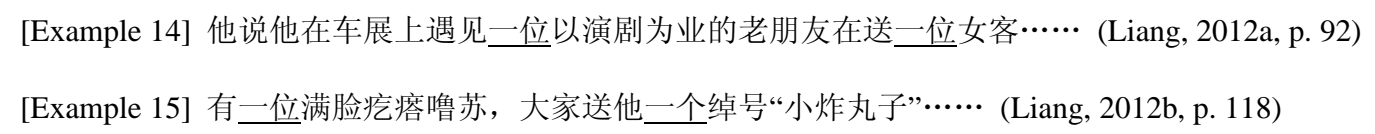

The right column is the number of indefinite articles that is counted from the first thousand words of the randomly-chosen proses in Liang's Sketches of a Cottager (see Table 4).

Table 4

Statistic of Indefinite Articles in Sketches of a Cottager

\begin{tabular}{lll}
\hline Publication time & Titles of works & Number of indefinite articles \\
\hline 1949 & 《孩子》Children & 12 \\
1949 & 《握手》Handshake & 17 \\
1973 & 《洗澡》Bathe & 17 \\
1973 & 《沉默》Silence & 17 \\
1982 & 《喝茶》Drinking Tea & 12 \\
1982 & 《台北家居》Home Life in Taipei & 14 \\
1986 & 《包装》Packaging & 16 \\
1986 & 《礼貌》Politeness & 12 \\
\hline
\end{tabular}

The numbers of indefinite articles above in Liang's three periods of vernacular Chinese literary creation change a little, which indicates that he has preserved the expression as a part of his writing.

\section{Conclusion}

Manipulation always means a kind of extraordinary alteration for some purposes. Liang Shih-chiu's manipulation of literary translation serves for the New Culture Movement which advocates new language expressions, new literary genres and new ideology. The method is to select Western classical works and use literal translation at sentence level. Liang's manipulation of literary creation serves for the vernacular Chinese 
and new Chinese literature. The exact method is his literary translation, through which new language expressions and literary genres have been introduced into Chinese and eventually become an essential part of modern Chinese language.

\section{References}

Hermans, T. (Ed.). (1985). The manipulation of literature: Studies in literary translation. London: Croom Helm. HU, S. (1993). The collection of Hu Shi's academic articles: The New Culture Movement. Beijing: Zhonghua Book Company. HU, S. (1996). Hu Shih's letters (Vol. One). Beijing: Peking University Press.

HU, S. (2004). Hu Shih's classics. Shanghai: Shanghai University Press.

Levefere, A. (Ed.). (2004a). Translation/history/culture: A sourcebook. Shanghai: Shanghai Foreign Language Education Press.

Levefere, A. (2004b). Translation, rewriting and the manipulation of literary fame. Shanghai: Shanghai Foreign Language Education Press.

Liang, S. C. (1967). Postscript of translation of Shakespeare's works. Taipei: Bibliography Quarterly Publishing House.

Liang, S. C. (1988). Romantic and classical/the discipline of literary. Beijing: People’s Literature Publishing House.

Liang, S. C. (Trans.). (2001a). William Shakespeare: Completed works 8 A Midsummer-Night's Dream. Beijing: China Radio Film \& TV Press.

Liang, S. C. (Trans.). (2001b). William Shakespeare: Completed works 13 Twelfth Night. Beijing: China Radio Film \& TV Press.

Liang, S. C. (Trans.). (2001c). William Shakespeare: Completed works 28 Romeo and Juliet. Beijing: China Radio Film \& TV Press.

Liang, S. C. (Trans.). (2001d). William Shakespeare: Completed works 40 The Sonnets. Beijing: China Radio Film \& TV Press. Liang, S. C. (2004). The collection of Liang Shih-chiu's essays. Beijing: China Society Press.

Liang, S. C. (2012a). Sketches of a cottager (Vol. One). Kunming: Yunnan People’s Publishing House.

Liang, S. C. (2012b). Sketches of a cottager (Vol. Two). Kunming: Yunnan People’s Publishing House. 